\title{
Where teenagers get their cigarettes: a survey of the purchasing habits of 13-16 year olds in 12 US communities
} K Michael Cummings, Eva Sciandra, Terry F Pechacek, Mario Orlandi,
William R Lynn, for the COMMIT Research Group
Department of Cancer Control and Epidemiology, Roswell Park Cancer Institute, Buffalo, New York 14263, USA

K M Cummings

E Sciandra

Department of Social and Preventive Medicine, State University of New York at Buffalo, Buffalo, New York USA

T F Pechacek

American Health Foundation, New York, New York, USA $M$ Orlandi

National Cancer Institute, Bethesda, Maryland, USA W R Lynn

Correspondence and requests for reprints to: $\mathrm{Dr}$ Cummings.

\begin{abstract}
Objective-To describe where teenage smokers obtain their cigarettes. Design and setting - Data were obtained from a 1990 school-based survey of ninth grade students (aged 13 to 16 years) conducted in 12 US communities participating in the National Cancer Institute's COMMIT trial.

Participants $\mathbf{- 4 0 1 0}$ ninth grade students (aged 13-16 years); 610 current cigarette smokers.

Results - Eighty-two per cent of ninth grade students answered that it would be easy for them to get cigarettes if they wanted some. Among current smokers, $67 \%$ said that they usually bought their own cigarettes. Small shops were identified as the most common site of purchase, used "often" or "sometimes" by $81 \%$ of those who reported smoking daily; large shops were used by $59 \%$ and vending machines by $38 \%$.

Conclusion - The findings from this survey underscore the need for communities to more vigorously enforce laws to prevent the sale of tobacco products to minors.
\end{abstract}

(Tobacco Control 1992; 1 : 264-7)

\section{Introduction}

Cigarette smoking kills more than 434000 Americans annually. ${ }^{1}$ Most tobacco victims are over the age of $35 .{ }^{1}$ However, the addiction that fosters tobacco use begins for the majority of smokers during adolescence. ${ }^{2}$ A recent US survey estimated that there are 2.6 million teenagers between the ages of 12 and 17 years who are current cigarette smokers - that is, smoked cigarettes on one or more of the 30 days preceding the survey. ${ }^{3}$

In an effort to deter minors from initiating and sustaining tobacco use most states have enacted laws that restrict the sale of tobacco to minors. ${ }^{4}$ Despite the existence of these laws, evidence indicates that minors have little difficulty purchasing tobacco products. ${ }^{5-9}$

Studies in several communities have shown that when tobacco access laws are enforced, cigarette sales to minors are markedly reduced. ${ }^{10-12}$ The ultimate question is whether reducing youth access to tobacco will lower smoking rates. In theory it should, given that most smokers start smoking as teenagers. Making it more difficult for minors to purchase tobacco products should help discourage teenagers from ever smoking and reinforce the perception of non-smoking as the social norm. Two recent studies support this view. In Leominster, Massachusetts, ${ }^{11}$ and Woodridge, Illinois, ${ }^{12}$ active law enforcement of local age restrictions on tobacco sales resulted in dramatic reductions in the prevalence of smoking among teenagers. Unfortunately, the programmes in Leominster and Woodridge are the exception rather than the rule.

This study uses data gathered in a 1990 survey of over 4000 ninth grade students from 12 US communities to examine where teenage smokers report obtaining their cigarettes. Strategies to limit minors' access to tobacco products are discussed.

\section{Methods}

From October to December 1990 data on the cigarette smoking behaviour of teenaged smokers aged 13-16 years were obtained from school-based surveys of students from a random sample of ninth grade classes in each of 12 communities. The communities that participated in the survey were Bellingham, Washington; Cedar Rapids, Iowa; Fitchburg and Leominster, Massachusetts; Medford and Ashland, Oregon; Paterson, New Jersey; Raleigh, North Carolina; Santa $\mathrm{Fe}$, New Mexico; Utica and Yonkers, New York; and Vallejo, California. Surveys were conducted as part of the ongoing evaluation of the National Cancer Institute's Community Intervention Trial for Smoking Cessation (COMMIT). ${ }^{13}$

The survey included both public and private schools with at least 50 students in the ninth grade. Forty-six of the $48(96 \%)$ eligible schools participated. Within participating schools, random samples of ninth grade classes were selected to be surveyed, generating a study group of 4716 students. As part of the informed consent procedure for the survey, parents of students in the selected classes were sent a letter notifying them of the survey and asking them to contact the school if they did not want their child to participate. In addition, at the time the survey was conducted students 
were given the opportunity to refuse participation. Trained staff, not teachers, administered the survey. Responses to the survey were anonymous. A total of 4010 usable surveys were collected, yielding an overall completion rate of $85 \%$.

The survey questionnaire included 78 questions and required one class period to complete. Topics covered in the questionnaire included current and past tobacco use behaviours, attitudes and knowledge about tobacco, and exposure to pro-tobacco and antitobacco information at school and in the community.

Current smokers were defined as those who reported smoking on one or more days during the 30 days preceding the survey. Current smokers were further subdivided into two groups: (a) regular smokers, defined as those who reported smoking daily during the 30 days preceding the survey, and $(b)$ occasional smokers, defined as those who reported themselves as current smokers but had not smoked daily during the preceding 30 days. Current smokers were asked to report whether they usually bought their own cigarettes and to indicate their usual sources for obtaining cigarettes - that is, vending machines, shops, adults, friends, and siblings. All students (current smokers and others) were asked to report how easy or difficult it was for them to get cigarettes.

Data from the 12 community samples were combined in the analysis because there was little variability observed across communities in responses to items on where cigarettes were obtained. Ninety-five per cent confidence intervals were calculated by the normal approximation method. ${ }^{14}$

\section{Results}

When asked the question "Do you think it would be difficult or easy to get cigarettes if you wanted some?" $82 \%$ (95\% confidence interval $81.2 \%$ to $83.6 \%$ ) of ninth grade students answered that it would be easy for them to get cigarettes.

Of the 4010 ninth grade students included in the survey, 680 were classified as current smokers; 324 of these were considered to be regular smokers and 356 occasional smokers. Among current smokers, $67 \% \quad(63.4 \%$ to $70 \cdot 6 \%$ ) reported that they usually bought their own cigarettes. Regular smokers were nearly twice as likely as occasional smokers to report buying their own cigarettes $(88 \%(84.4$ to 91.6$)$ v $47 \%(41.7 \%$ to $52.3 \%))$.

Table 1 shows the sources current smokers reported usually using to obtain cigarettes Among occasional smokers the most prevalent source of cigarettes was friends and siblings followed by shops, vending machines, and adults. Among regular smokers the most prevalent source of cigarettes was shops, followed by friends and siblings, vending machines, and adults.

Table 2 shows regular smokers' reported prevalence of purchasing cigarettes from vending machines, large shops such as a supermarket, and small shops such as a convenience store or petrol station. Small shops were identified as the most popular source of purchasing cigarettes, followed by large shops and vending machines.

\section{Discussion}

The findings from this study agree with those of studies examining where youth obtain cigarettes. ${ }^{3,15-17}$ The Centers for Disease Control included several questions on youth access to cigarettes in its 1989 Teenage Attitudes and Practice Survey of adolescents 12-18 years of age. ${ }^{3}$ Among 12-17 year olds who had smoked in the preceding 30 days, $58 \%$ said they usually bought their own cigarettes. Small shops were identified as the most common site of purchase, used "often" or "sometimes" by $85 \%$ of smokers who reported that they usually

Table 1 Usual sources ${ }^{\star}$ of cigarettes reported by ninth grade smokers by prevalence of smoking. Values are percentages $(95 \%$ confidence intervals)

\begin{tabular}{lccc}
\hline & \multicolumn{2}{c}{ Prevalence of smoking } & \\
\cline { 2 - 3 } Source of cigarettes & Occasional smoker $(n=344)$ & Regular smoker $(n=317)$ & All current smokers $(n=661)$ \\
\hline Shop & $39 \cdot 8(34 \cdot 6$ to $45 \cdot 0)$ & $74 \cdot 8(70 \cdot 0$ to $79 \cdot 6)$ & $56 \cdot 6(52 \cdot 8$ to $60 \cdot 4)$ \\
Vending machine & $20 \cdot 9(16 \cdot 6$ to $25 \cdot 2)$ & $34 \cdot 7(29.5$ to $39 \cdot 9)$ & $27 \cdot 5(24 \cdot 1$ to $30 \cdot 9)$ \\
Friend or sibling & $64 \cdot 5(59 \cdot 4$ to $69 \cdot 6)$ & $48 \cdot 6(43 \cdot 1$ to $54 \cdot 1)$ & $56 \cdot 9(53 \cdot 1$ to $60 \cdot 7)$ \\
Parents or adults & $9 \cdot 6(6 \cdot 5$ to $12 \cdot 7)$ & $25 \cdot 2(20 \cdot 4$ to $30 \cdot 0)$ & $17 \cdot 1(14 \cdot 2$ to $20 \cdot 0)$ \\
\hline
\end{tabular}

* Respondents were allowed to report multiple sources for getting cigarettes.

Table 2 Reported prevalence among regular smokers ${ }^{\star}$ of purchasing cigarettes from vending machines and large and small shops

\begin{tabular}{|c|c|c|c|}
\hline \multirow[b]{2}{*}{ Prevalence of purchasing } & \multicolumn{3}{|c|}{ Source of purchasing cigarettes } \\
\hline & Vending machine $(n=320)$ & Large shopf $(n=322)$ & Small shop $\ddagger(n=323)$ \\
\hline Often & $16 \cdot 2(12 \cdot 2$ to $20 \cdot 2)$ & $34.5(29 \cdot 3$ to $39 \cdot 7)$ & $61.0(55.7$ to $66 \cdot 3)$ \\
\hline Sometimes & $21.6(17 \cdot 1$ to $26 \cdot 1)$ & $24.2(19.5$ to 28.9$)$ & $19.5(15.2$ to 23.8$)$ \\
\hline Rarely or never & $62.2(56.9$ to 67.5$)$ & $41.3(35 \cdot 9$ to $46 \cdot 7)$ & $19.5(15.2$ to 23.8$)$ \\
\hline
\end{tabular}

* Sample size $=324$

† For example, a supermarket.

$\ddagger$ For example, a convenience store. 
bought their own cigarettes. ${ }^{3}$ Similar results were reported in a 1989 study commissioned by the National Automatic Merchandising Association. ${ }^{17}$ This is a trade association for companies that sell cigarettes through vending machines. Using a mall-intercept survey method, the study assessed the cigarette purchasing habits of 1015 teenage smokers (aged 13 to 17 years) in 20 US cities. Seventy-two per cent of smokers surveyed said that they obtained their cigarettes by purchasing them. Among those who purchased their own cigarettes, $85 \%$ said they "often" or "occasionally" bought from a shop compared with $22 \%$ from vending machines. Convenience stores and petrol stations were the most frequently mentioned over-the-counter locations for purchasing cigarettes.

Numerous studies have documented that teenagers have little trouble in buying cigarettes where such sales are illegal. ${ }^{5-9}$ Data from this study reinforce this conclusion, finding that $82 \%$ of ninth grade students considered it "easy" to get cigarettes if they wanted them. Despite differences in the age restriction laws governing the sale of tobacco products across the 12 communities included in this study, including one community with no age restriction (Santa Fe, New Mexico), there was no significant difference in ninth grade students who reported difficulty in getting cigarettes. The mere existence of a law prohibiting the sale of tobacco products to minors seems to have little effect on how easy it is for teenagers to purchase cigarettes.

Regular smokers from Santa Fe were somewhat less likely than their counterparts in other communities to report purchasing cigarettes from vending machines (18\% $(7.5 \%$ to $28.5 \%)$ $v 38 \%(32.2 \%$ to $43.8 \%))$. This finding suggests that when no age restriction exists, teenage smokers will opt to purchase their cigarettes over-the-counter rather than from vending machines because of the lower cost. However, in all but one community (Vallejo, California) regular smokers identified shops as the most prevalent source of cigarettes. In Vallejo vending machines were reported as the most prevalent source of cigarettes $(56 \%$ $(23.6 \%$ to $88.4 \%)$ ) followed by shops ( $44 \%$ $(11.6 \%$ to $76 \cdot 4 \%)$ ).

The public supports stronger limits on children's access to, and use of, tobacco products. ${ }^{18}$ US Department of Health and Human Services Secretary Louis Sullivan has called on states to enact comprehensive tobacco access legislation that would $(a)$ create a retailer licensing system for tobacco similar to that used for alcoholic beverages; $(b)$ make the sale of tobacco to a minor a civil offence to avoid the costs and delays of the criminal court system; (c) establish a graduated schedule of penalties for illegal sales, including monetary fines and licence suspensions; and $(d)$ set the minimum age for purchase at 19 years.

Policymakers may also consider increasing the cost of tobacco products through taxation or other means - for example, retail tobacco licence fees - as a strategy for discouraging teenage smoking. Studies have shown that compared with those of adults, teenagers purchasing patterns are more sensitive to increases in the cost of cigarettes. ${ }^{1}$

Eliminating the profit gained from selling tobacco products to minors might also encourage the tobacco industry to act more responsibly about keeping their products out of the hands of children. Policymakers could consider levying an illegal drug profit tax on the cigarette industry to recover profits obtained from the sale of cigarettes to minors. ${ }^{19}$ A recent study estimated that in 1991 approximately 260 million packs of cigarettes were sold illegally to teenagers in the United States, accounting for over $\$ 90$ million in profits to the tobacco industry (K M Cummings et al, unpublished data).

Finally, tax revenue collected from the illegal sale of cigarettes to minors could be earmarked to finance tobacco control interventions, including programmes to enforce tobacco access laws.

In view of the size of the tobacco problem in the United States, it is distressing to observe the low level of tobacco control activities carried out by government agencies charged with protecting public health. For example, a 1989 survey of state health departments found that the mean state budget (excluding California) devoted to tobacco-related health activities was $\$ 90917$. The state funds varied from no funds (27 states) to $\$ 151$ million in California, where a portion of the state cigarette excise tax is earmarked to tobacco control activities. ${ }^{20}$ Though many non-governmental agencies sponsor a wide range of tobacco control activities, in nearly all communities it is safe to conclude that the resources devoted to combat tobacco use are substantially lower than the resources dedicated by the tobacco industry to encourage smoking.

Until recently the federal government has taken no action to regulate the access of minors to tobacco. In July 1992 Congress passed an important amendment to the ADAMHA (Alcohol, Drug Abuse, and Mental Health Administration) Reorganization Act designed to discourage tobacco use by youth. The Synar amendment, named for the member of Congress, Mike Synar, who offered this amendment to the ADAMHA bill, provides that as a condition of receiving block grant funds for substance abuse prevention and treatment, states must enact and enforce a law prohibiting the sale or distribution of tobacco products to individuals under 18 years of age. Specifically, states will be required to conduct annually random, unannounced inspections of places where tobacco products are sold and to submit a report to the Secretary of Health and Human Services describing the activities carried out by the state to enforce the tobacco access law during the preceding year. If a state fails to show a reasonable effort to enforce the law preventing tobacco sales to minors, then it will lose between $10 \%$ and $40 \%$ (depending on the year) of its ADAMHA grant funds. (ADAMHA block grant awards authorised for the fiscal year 1993 range from $\$ 2.0$ million for Wyoming to $\$ 201.2$ million for California.) As 
no state government wishes to risk losing substantial federal funding, the Synar amendmend will probably serve as a new impetus for state and local governments to enact meaningful new legislation to curtail tobacco sales to minors.

1 US Department of Health and Human Services. Reducing the health consequences of smoking : 25 years of progress. $A$ report of the Surgeon General, 1989. Atlanta, Georgia Centers for Disease Control, Office on Smoking and Health, 1989. (DHHS Publication No (CDC) 89-8411.

2 Centers for Disease Control. Differences in the age of smoking initiation between blacks and whites - United smoking initiation between black
States. $M M W R$ 1991; 40: 754-7.

3 Centers for Disease Control. Accessibility of cigarettes to youths aged 12-17 years - United States, 1989. MMWR 1992 ; 41: 485-8.

4 Centers for Disease Control. State laws restricting minors' access to tobacco. MMWR 1990; 39: 349-53.

5 Office of Inspector General. Youth access to cigarettes. Washington, DC: US Department of Health and Human Services, 1990 .

6 Skretny MT, Cummings KM, Sciandra R, Marshall J. An intervention to reduce the sale of cigarettes to minors. NY State f Med 1990; 90: 54-5.

7 DiFranza JR, Norwood BD, Garner DW, Tye JB. Legislative efforts to protect children from tobacco. Legislative efforts to pro
$\mathcal{J} A M A 1987 ; 257: 3387-9$.

8 Centers for Disease Control. Cigarette sales to minors Colorado, 1989. MMWR 1990; 39: 794-5, 801.
9 Hoppock RC, Houston TP. Availability of tobacco products to minors. F Fam Pract $1990 ; 30: 174-6$

10 Feighery E, Altman DG, Shaffer G. The effects of combining education and enforcement to reduce tobacco combining education and enforcement to red

sales to minors. FAMA $1991 ; 266: 3168-71$.
11 DiFranza JR, Carlson RP, Caissey RE Jr. Reducing youth access to tobacco. Tobacco Control 1992; 1: 58

12 Jason LA, Ji PY, Anes MD, Birkhead SH. Active enforcement of cigarette control laws in the prevention of cigarette sales to minors. $\mathcal{f} A M A 1991 ; 266$ : $3149-53$.

13 COMMIT Research Group. Community intervention tria for smoking cessation (COMMIT): summary of design and intervention. 7 Natl Cancer Inst 1991; 83:1620-8.

14 Brown BW, Hollander M. Statistics: a biomedical intro duction. New York: Wiley, 1977.

15 Stenwick RS, Fish DG, Manfreda J, Gelsky D, Skuben A Where Manitoba children obtain their cigarettes. Can Med Assoc 7 1987; 137: 405-8.

16 Forster JL, Kunt-Inge V, Jeffrey RW. Sources of cigarettes for tenth graders in two Minnesota cities. Health Educ for tenth graders in
Res $1989 ; 4: 45-50$

17 Findings from the study of teenage cigarette smoking purchasing behavior. Prepared for the National Automatic Merchandising Association. Chicago: Response Research, 1989

18 Centers for Disease Control. Public attitudes regarding limits on public smoking and regulation of tobacco sales and advertising - 10 US communities, 1989. MMWR $1991 ; 40: 344-5,351-3$.

19 DiFranza JR, Tye JB. Who profits from tobacco sales to children? f $A M A$ 1990; 263: 2784-7.

20 Centers for Disease Control. State tobacco prevention, control activities: results of 1989-1990 Association of State Territorial Health Officials (ASTHO) Survey Final Report. $M M W R$ 1991; 40 (No R-11): 1-41.

\section{Translations of abstract}

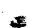

The Chinese translation will be published in the next issue.

\section{Donde obtienen los adolescentes sus cigarrillos: encuesta de los hábitos de adquisición de muchachos de 13 a 16 años de edad en 12 comunidades de EUA}

$\mathrm{K}$ Michael Cummings et al

\section{Resumen}

Objetivo: Describir dónde obtienen sus cigarrillos los fumadores adolescentes.

Diseño y entorno: Los datos se obtuvieron de una encuesta de 1991 entre los estudiantes de noveno grado (de 13 a 16 años de edad) realizada en escuelas de 12 comunidades de EUA que participaban en el ensayo COMMIT del Instituto Nacional del Cáncer.

Participantes: 4010 estudiantes de noveno grado (de 13 a 16 años de edad); 610 fumadores de cigarrillos actuales.

Resultados: Ochenta y dos por ciento de los alumnos de noveno grado respondieron que les resultaría fácil conseguir cigarrillos si quisieran. Entre los fumadores actuales, $67 \%$ dijeron que generalmente compraban sus propios cigarrillos. Las tiendas pequeñas se identificaron como el sitio más común de la compra, pues a ellas concurrían "a menudo" o "a veces" $81 \%$ de los que declararon fumar todos los dias; las tiendas grandes fueron empleadas por $59 \%$ y los distribuidores automáticos por $38 \%$.

Conclusion: Los resultados de esta encuesta subrayan la necesidad de que las comunidades hagan cumplir con más vigor las leyes para impedir la venta de los productos de tabaco a los menores. 